\title{
HASIL BELAJAR, PEMAHAMAN KONSEP DAN BERPIKIR KREATIF SISWA DALAM PEMBELAJARAN INKUIRI BEBAS DAN INKUIRI TERBIMBING
}

\author{
Ni Wayan Suparmi \\ STKIP Citra Bakti, Nusa Tenggara Timur, Indonesia \\ Email: wayansupar85@yahoo.com
}

\begin{abstract}
Abstrak
Penelitian ini bertujuan untuk mengetahui pengaruh dua model pembelajaran inkuiri terhadap pemahaman konsep dan berpikir kreatif. Rancangan dalam penelitian ini adalah pre-tes post-test control group design. Subjek penelitian adalah semua siswa kelas X SMK Negeri 3 Singaraja, Bali, yang diambil berdasarkan teknik random class sampling. Data pemahaman konsep dikumpulkan dengan 25 item tes pemahaman konsep, sedangkan data berpikir kreatif siswa dikumpulkan dengan 24 item tes berpikir kreatif. Data yang diperoleh dianalisis dengan statistik deskriptif dan MANOVA. Temuan dalam penelitian ini adalah. (1) Terdapat perbedaan pemahaman konsep dan berpikir kreatif antara siswa yang diberikan model pembelajaran Inkuiri bebas dan inkuiri terbimbing $(F=16,694 ; p<0,05)$. (2) Terdapat perbedaan pemahaman konsep antara siswa yang dibelajarkan dengan model pembelajaran inkuiri bebas dan terbimbing $(\mathrm{F}=16,694 ; \mathrm{p}<0,05)$. (3) Terdapat perbedaan berpikir kreatif siswa yang diberikan model pembelajaran inkuiri bebas dan terbimbing $(F=32,086 ; p<0,05)$.
\end{abstract}

Kata kunci: berpikir kreatif, model inkuiri, pemahaman konsep

\begin{abstract}
This study aims to determine the effect of two models of inquiry learning on understanding concepts and creative thinking. The design in this study was a pre-test post-test control group design. The research subjects were all class X students of SMK Negeri 3 Singaraja, Bali, which were taken based on random class sampling techniques. Data on understanding concepts is collected with 25 items of concept understanding tests, while students' creative thinking data are collected with 24 items of creative thinking tests. The data obtained were analyzed by descriptive statistics and MANOVA. The findings in this study are. (1) There are differences in conceptual understanding and creative thinking between students who are given the free inquiry and guided inquiry learning model $(\mathrm{F}=16,694 ; \mathrm{p}<0.05)$. (2) There are differences in conceptual understanding between students who are taught with free and guided inquiry learning models $(F=16,694 ; p<0,05)$. (3) There are differences in creative thinking of students given a free and guided inquiry learning model $(\mathrm{F}=32,086 ; \mathrm{p}<0,05)$.
\end{abstract}

Keywords: creative thinking, inquiry model, concept understanding

\section{Pendahuluan}

Kemampuan beradaptasi, fleksibel, dan belajar sepanjang hayat merupakan kunci sukses dunia kerja abad 21 (Suma, 2009). Esensi dari pernyataan tersebut adalah perlunya upaya memakmurkan kehidupan masyarakat yang maju dan kompetitif. Untuk mencapai hal tersebut, harus menjadikan pendidikan sebagai barometer dan indikator majunya sebuah negara di era belajar. Jatuh bangunnya sebuah negara bergantung pada kesuksesan pelaksanaan pendidikan yang dibuktikan dengan produk-produk/output pendidikan berkualitas.

Mengingat pendidikan idealnya proses sepanjang hayat, maka lulusan atau keluaran dari suatu proses pendidikan tertentu harus dipastikan memiliki kompetensi yang berkualitas sehingga esensi tujuan pendidikan dapat dicapai. Pendidikan harus dilaksanakan dengan sebaik-baiknya untuk memperoleh hasil yang maksimal. Hasil yang maksimal dapat dicapai dengan terlaksananya pendidikan yang tepat waktu dan tepat guna untuk mencapai tujuan pendidikan. Pendidikan tepat waktu yaitu pendidikan yang diberikan sejak dini sedangkan pendidikan tepat guna adalah pendidikan yang dapat digunakan sebagai upaya untuk mencapai tujuan pendidikan yang diharapkan. Tujuan yang diharapkan yaitu meningkatkan kualitas sumber daya manusia (SDM). Selain itu, globalisasi menuntut peningkatan daya saing dan kompetisi yang terbuka, sehingga pendidikan sebagai media transformasi pengembangan sumber daya manusia harus diorientasikan dan ditekankan untuk bisa terselenggaranya pendidikan yang bermakna. Pendidikan yang bermakna akan dapat memberi kontribusi positif pada kehidupan, dan akan dapat memenuhi tuntutan kehidupan masa depan (Dasna, Laksana, \& Sudatha, 2015).

Pada kenyataannya, sampai sekarang ini bangsa Indonesia memiliki permasalahan pada mutu pendidikan. Mutu pendidikan indonesia masih tergolong sangat rendah dibandingkan dengan negara-negara lain di dunia. Hasil survei TIMSS (Trends in International Mathematic and Science Study) tahun 2011 menunjukkan bahwa rata-rata skor prestasi sains adalah sebesar 406, yang mengalami penurunan dari tahun 2007 (Provasnik, et al., 2012). Dari hasil survei TIMS, rata-rata skor prestasi sains siswa Indonesia di bawah skor rata-rata yaitu 500, dan hanya mencapai Low International Benchmark.

Dengan capaian tersebut, skor rata-rata sains siswa Indonesia hanya mampu mengenali sejumlah fakta dasar tetapi belum mampu mengkomunikasikan dan mengaitkan berbagai topik sains, apalagi menerapkan 
konsep-konsep yang kompleks dan abstrak. Berdasarkan paparan tersebut, mengindikasikan pemahaman konsep sains dan daya nalar siswa dalam berkreativitas masih rendah yang bermuara pada rendahnya kemampuan berpikir kreatif siswa.

Bersamaan dengan itu, pembelajaran IPA yang berlangsung saat ini masih bercorak teoritis, hapalan dan hitungan. Selain itu, proses pembelajaran yang masih didominasi oleh guru menyebabkan siswa kurang mengembangkan pengetahuan dan kreativitasnya dalam proses pembelajaran. Masalah-masalah yang muncul tersebut tentunya akan berdampak terhadap pemahaman konsep serta kreativitas siswa dalam waktu jangka panjang serta tidak mampu mengaplikasikannya dalam kehidupan nyata.

Di sisi lain, IPA berhubungan dengan cara mencari tahu tentang alam secara sistematis, sehingga IPA bukan hanya penguasaan kumpulan sistematis dan IPA bukan hanya penguasaan kumpulan pengetahuan yang berupa fakta-fakta, konsep-konsep atau prinsip-prinsip saja, tetapi juga merupakan suatu proses penemuan (Sri Sulistyorini, 2007: 39). Jadi dapat dikatakan bahwa IPA adalah ilmu yang mempelajari peristiwa-peristiwa yang terjadi di alam dengan melakukan observasi, eksperimentasi, penyimpulan, penyusunan teori agar siswa mempunyai pengetahuan, gagasan dan konsep yang terorganisasi tentang alam sekitar, yang diperoleh dari pengalaman melalui serangkaian proses ilmiah antara lain penyelidikan, penyusunan dan penyajian gagasangagasan yang merupakan suatu proses penemuan.

Adapun salah satu model pembelajaran yang dapat memfasilitasi proses penemuan dalam belajar mandiri secara kreatif adalah model pembelajaran Inkuiri. Model Pembelajaran Inkuiri merupakan satu komponen penting dalam pendekatan konstruktivistik yang telah memiliki sejarah panjang dalam inovasi atau pembaruan pendidikan. Dalam pembelajaran dengan penemuan atau inkuiri, siswa didorong untuk belajar sebagian besar melalui keterlibatan aktif mereka sendiri dengan konsep-konsep dan prinsip-prinsip, dan guru mendorong siswa untuk memiliki pengalaman dan melakukan percobaan yang memungkinkan mereka menemukan prinsip-prinsip untuk diri mereka sendiri. metode pembelajaran inkuiri melatih siswa mengemukakan pendapat dan menemukan sendiri pengetahuan yang berguna untuk memecahkan masalah yang dihadapinya. Penggunaan metode inkuiri secara efektif dan efisien akan mengurangi monopoli guru dalam penguasaan jalannya pembelajaran, dan kebosanan siswa dalam menerima pelajaran akan berkurang (Putri et al., 2012). Model inkuiri yang didefinisikan sebagai suatu rangkaian kegiatan belajar yang melibatkan secara maksimal seluruh kemampuan siswa untuk mencari dan menyelidiki secara sistematis, kritis, logis, dan analisis sehingga mereka dapat merumuskan sendiri penemuan dengan penuh percaya diri.

Model pembelajaran Inkuiri menekankan kepada proses mencari dan menemukan. Materi pelajaran tidak diberikan secara langsung. Peran siswa dalam strategi ini adalah mencari dan menemukan sendiri materi pelajaran, sedangkan guru berperan sebagai fasilitator dan pembimbing siswa untuk belajar. Pandey dkk., (2011) menyatakan bahwa pembelajaran inkuiri memberikan pengalaman belajar yang sangat penting guna meningkatkan pemahaman dan melibatkan siswa secara langsung dalam proses pembelajaran (student centered).

Siswa yang belum berpengalaman dalam inkuiri dapat diterapkan model pembelajaran inkuiri terbimbing. Model pembelajaran inkuiri terbimbing suatu model pembelajaran yang dalam pelaksanaannya guru menyediakan bimbingan atau petunjuk cukup luas kepada siswa. Sebagian perencanaannya dibuat oleh guru, siswa tidak merumuskan problem atau masalah. Dalam pembelajaran inkuiri terbimbing guru tidak melepas begitu saja kegiatan-kegiatan yang dilakukan oleh siswa. Guru harus memberikan pengarahan dan bimbingan kepada siswa dalam melakukan kegiatan-kegiatan sehingga siswa yang berifikir lambat atau siswa yang mempunyai intelegensi rendah tetap mampu mengikuti kegiatan-kegiatan yang sedang dilaksanakan dan siswa mempunyai intelegensi tinggi tidak memonopoli kegiatan oleh sebab itu guru harus memiliki kemampuan mengelola kelas yang bagus.

Sementara, dalam pembelajaran inkuiri bebas peserta didik melakukan penelitian secara mandiri bagaikan seorang ilmuwan. Kegiatan pembelajarannya dimulai dari mengidentifikasi dan merumuskan masalah secara mandiri dari berbagai topik yang hendak diselidikinya. Kemudian dilanjutkan dengan perumusan hipotesis, merancang dan melakukan percobaan, mengumpulkan dan menganalisis data, menginterpretasi hasil analisis data dan melakukan pembahasan temuannya, dan diakhiri dengan penarikan kesimpulan Sadia (2014:131).

Antara model pembelajaran inkuiri terbimbing dan model pembelajaran inkuiri bebas memiliki perbedaan yang sangat signifikan. Pada model pembelajaran inkuiri terbimbing guru tidak melepas siswa begitu saja dalam suatu proses pembelajaran. Siswa ditingkat dasar seperti TK, SD, dan SMP sangat cocok diterapkan model pembelajaran inkuiri terbimbing.

\section{Metode}

Penelitian ini adalah penelitian eksperimen semu (quasi exsperiment). Desain penelitian ini menggunakan desain eksperimen pretest-posttest control group design. Populasi dalam penelitian ini adalah seluruh siswa kelas X SMK Negeri 3 Singaraja, adapun jumlah seluruh populasi yakni berjumlah 120 orang, yang terdistribusi ke dalam empat kelas antara lain kelas XTKJ 1, XTKJ 2, XTKJ 3,dan XTKJ 4. Pemilihan sampel dilakukan dengan cara random kelas sampling. Kelas yang telah terpilih dari proses random pertama kemudian dirandom kembali untuk menentukan kelas yang menggunakan model pembelajaran inkuiri bebas (MPIB) dan kelas yang menggunakan model pembelajaran inkuiri terbimbing (MPIT). 
Penelitian ini menggunakan tahapan, yaitu (1) orientasi dan observasi awal, (2) merancang instrumen penelitian (membuat RPP dan LKS), (3) observasi awal, (4) uji coba instrumen penelitain, (5) revisi instrumen, (6) merancang perangkat pembelajaran, (7) mengadakan tes awal (pre-test), (8) memberikan perlakuan (9) mengadakan test akhir (post-test), (10) melakukan analisis data, (11) penyelesaian. Penelitian ini menggunakan dua instrumen, terdiri dari; (1) tes pemahaman konsep dan (2) tes keterampilan berpikir kreatif. Kedua tes ini juga berfungsi sebagai tes awal untuk mengumpulkan data pra-pemahaman konsep dan pra-keterampilan berpikir kreatif dan tes awal pra-pemahaman konsep yang dilakukan dengan mengadakan tes awal bagi seluruh sampel baik yang kelas eksperimen I maupun kelas eksperimen II.

Data yang diperlukan dalam penelitian ini adalah nilai rata-rata kemampuan pemahaman konsep siswa yang berjumlah 45 soal objektif tes yang diperluas. Permasalahan dalam tes menyangkut masalah akademik dan permasalahan realistik. Berdasarkan cakupan materi dan dengan mempertimbangkan jumlah jam pelajaran fisika di SMK serta mempertimbangkan kemungkinan adanya item-item yang tidak memenuhi syarat dari hasil uji coba maka dipilih 25 butir tes untuk digunakan pada akhir tes. Kriteria penilaian tes kreativitas menggunakan rubrik dengan rentangan skor 0-4. Untuk mengukur kreativitas siswa, maka digunakan tes berpikir kreatif yang diadaptasi dari Munandar (1999). Tes yang diadaptasi tersebut terdiri dari enam sub tes yang semuanya mengukur dimensi operasional berpikir kreatif dengan dimensi konten verbal tetapi berbeda dalam dimensi produk. Setiap subtes mengukur aspek yang berbeda dari berpikir kreatif Tes ini terdiri dari enam sub tes, yaitu; (1) permulaan kata, (2) menyusun kata, (3) membentuk kalimat tiga huruf, (4) sifat-sifat yang sama, (5) macammacam penggunaan, dan (6) apa akibatnya.

Untuk melakukan analisis data digunakan dua teknik analisis yaitu analisis statistik deskriptif dan analisis multivariat (MANOVA). Analisis data untuk menguji hipotesis digunakan multivariate analysis of variance (MANOVA) dengan bantuan SPSS. Pengujian hipotesis nol dilakukan dengan taraf signifikansi 5\%. Analisis MANOVA mensyaratkan beberapa asumsi. Asumsi yang harus dipenuhi adalah uji normalitas sebaran data, uji homogenitas, uji homogenitas matriks-matriks varians, uji kolinieritas, uji hipotesis dan uji lanjut dengan Least Significant Diference (LSD).

\section{Hasil dan Pembahasan}

Hasil penelitian menunjukkan bahwa terdapat perbedaan pemahaman konsep siswa yang signifikan antara kelompok siswa yang belajar dengan model pembelajaran inkuiri bebas dan model pembelajaran inkuiri terbimbing dengan $\mathrm{F}=16,694 ; \mathrm{p}<0,05$. Berdasarkan hasil statistik deskriptif dapat dilihat bahwa rata-rata gain score pemahaman konsep siswa kelompok MPIB adalah 0,63 dengan kategori sedang dibandingkan dengan kelompok MPIT yang memiliki skor rata-rata 0,53 dengan kategori sedang. Gain score MPIB lebih besar dibandingkan MPIT. Dengan kata lain MPIB lebih unggul dibandingkan dengan MPIT dalam pencapaian pemahaman konsep. Untuk skor berpikir kreatif, dilihat dari rata-rata gain score berpikir kreatif MPIB =0,61 dengan kategori sedang dan MPIT $=0,46$ dengan kategori sedang. Hasil ini menunjukkan bahwa adanya perbedaan, di mana rata-rata gain score berpikir kreatif kelompok siswa yang mengikuti pembelajaran dengan model pembelajaran inkuiri bebas MPIB) lebih tinggi dibandingkan dengan rata-rata gain score berpikir kreatif kelompok siswa yang mengikuti pembelajaran dengan menggunakan model pembelajaran inkuiri terbimbing (MPIT).

Hal ini sejalan dengan penelitian yang dilakukan oleh Putra (2016) degan hasil sebagai berikut. (1) terdapat perbedaan literasi sains dan konsep diri siswa antara kelompok siswa yang belajar dengan model pembelajaran inkuiri terbimbing, siswa yang belajar dengan model pembelajaran inkuiri bebas, dan siswa yang belajar dengan model pembelajaran langsung $(\mathrm{F}=7,169 ; \mathrm{p}<0,05)$. (2) terdapat perbedaan literasi sains antara kelompok siswa yang belajar dengan model pembelajaran inkuiri terbimbing, siswa yang belajar dengan model pembelajaran inkuiri bebas, dan siswa yang belajar dengan model pembelajaran langsung $(\mathrm{F}=10,006 ; \mathrm{p}<0,05)$. (3) terdapat perbedaan konsep din siswa antara kelompok siswa yang belajar dengan model pembelajaran inkuiri terbimbing, siswa yang belajar dengan model pembelajaran inkuiri bebas, dan siswa yang belajar dengan model pembelajaran langsung $(\mathrm{F}=11,975 ; \mathrm{p}<0,05)$. Temuan tersebut juga menguatkan bahwa literasi sains dan konsep diri siswa yang belajar menggunakan model pembelajaran inkuiri terbimbing lebih baik dibandingkan kelompok siswa yang belajar menggunakan model pembelajaran inkuiri bebas dan model pembelajaran langsung.

Pencapaian pemahaman konsep siswa yang dibelajarkan dengan model pembelajaran inkuiri bebas (MPIB) dan model pembelajaran inkuiri terbimbing (MPIT), hasil penelitian menunjukkan bahwa terdapat perbedaan pemahaman konsep siswa yang signifikan antara kelompok siswa yang belajar dengan model pembelajaran inkuiri bebas dan model pembelajaran inkuiri terbimbing dengan $F=16,694$; $p<0,05$. Berdasarkan hasil statistik deskriptif dapat dilihat bahwa rata-rata gain score pemahaman konsep siswa kelompok MPIB adalah 0,63 dengan kategori sedang dibandingkan dengan kelompok MPIT yang memiliki skor rata-rata 0,53 dengan kategori sedang. Gain score MPIB lebih besar dibandingkan MPIT. Dengan kata lain MPIB lebih unggul dibandingkan dengan MPIT dalam pencapaian pemahaman konsep.

Hal ini sejalan dengan temuan Yustini (2015) yang menunjukkan bahwa: (1) terdapat perbedaan pemahaman konsep biologi antara siswa yang belajar melalui model pembelajaran inkuiri bebas dan siswa yang belajar melalui model pembelajaran inkuiri terbimbing $(F=7,208 ; p<0,05),(2)$ terdapat pengaruh interaksi antara 
model pembelajaran dan gaya kognitif terhadap pemahaman konsep biologi siswa $(\mathrm{F}=65,451 ; \mathrm{p}<0,05),(3)$ terdapat perbedaan pemahaman konsep biologi antara kelompok siswa yang belajar melalui model pembelajaran inkuiri bebas dan siswa yang belajar melalui inkuiri terbimbing untuk siswa yang memiliki gaya kognitif field dependent $(\mathrm{F}=14,696$; $\mathrm{p}<0,05)$, (4) terdapat perbedaan pemahaman konsep biologi antara kelompok siswa yang belajar melalui model pembelajaran inkuiri bebas dan siswa yang belajar melalui inkuiri terbimbing tintuk siswa yang memiliki gaya kognitiffield independent (F 57,707; $\mathrm{p}<0,05)$.

Pengaruh model pembelajaran inkuiri bebas (MPIB) dan model pembelajaran inkuiri terbimbing (MPIT) untuk pencapaian berpikir kreatif siswa, hasil penelitian menunjukkan bahwa terdapat perbedaan berpikir kreatif siswa yang signifikan antara kelompok siswa yang belajar dengan model pembelajaran inkuiri bebas dan model pembelajaran inkuiri terbimbing, dilihat dari rata-rata gain score berpikir kreatif MPIB =0,61 dengan kategori sedang dan MPIT = 0,46 dengan kategori sedang. Hasil ini menunjukkan bahwa adanya perbedaan, di mana rata-rata gain score berpikir kreatif kelompok siswa yang mengikuti pembelajaran dengan model pembelajaran inkuiri bebas MPIB) lebih tinggi dibandingkan dengan rata-rata gain score berpikir kreatif kelompok siswa yang mengikuti pembelajaran dengan menggunakan model pembelajaran inkuiri terbimbing (MPIT).

Penggunaan pendekatan inkuiri dalam pembelajaran dilandasi pandangan konstruktivisme. Menurut pandangan konstruktivistik, belajar merupakan suatu proses pembentukan pengetahuan. Pembentukan ini harus dilakukan oleh si pebelajar. Siswa harus aktif melakukan kegiatan, aktif berpikir, menyusun konsep dan memberi makna tentang hal-hal yang sedang dipelajari. Guru memang dapat dan harus mengambil prakarsa untuk menata lingkungan yang memberi peluang optimal bagi terjadinya belajar. Namun yang akhirnya paling menentukan terwujudnya gejala belajar adalah kreativitas siswa sendiri. Dengan istilah ini, dapat dikatakan bahwa hakekatnya kendali belajar sepenuhnya ada pada siswa.

Dengan adanya model pembelajaran inkuiri, siswa yang tidak terbiasa dengan proses pembelajaran inkuri akan merasa terbimbing untuk mengembangkan dan menggali seberapa besar pengetahuan yang mereka miliki. Sehingga siswa-siswa yang memiliki kemampuan rendah akan terbimbing untuk mendapatkan informasi lebih banyak, dengan kata lain siswa yang memiliki kemampuan rendah akan merasa seimbang dengan siswa yang memiliki kemampuan tinggi. Dengan hal tersebut secara tidak langsung siswa akan aktif dalam proses pembelajaran setelah guru memberikan bimbingan dan mencari informasi yang sebanyak-banyaknya tentang materi pelajaran, yang nantinya akan menunjang pengetahuan mereka.

Dengan pengetahuan yang mereka miliki, siswa akan memiliki kreativitas yang baik. Dengan model pembelajaran inkuiri, antara siswa dan guru sama-sama memiliki peran dalam proses pembelajaran, yang tentunya lebih menekankan kepada siswa. Dengan kata lain peran guru hanya membimbing siswa untuk menemukan konsep-konsep tentang materi pelajaran yang mampu meningkatkan pengetahuan siswa itu sendiri. Sehingga pengetahuan yang mereka peroleh dalam proses pembelajaran akan tepat mengacu pada materi yang sedang mereka pelajari. Serta konsep-konsep yang mereka temukan akan diingat dalam jangka panjang atau lebih lama dibandingkan dengan pembelajaran konvensional karena pembelajaran konvensional guru berperan penting sehingga siswa kurang tertarik untuk belajar maupun mengingat konsep-konsep yang diberikan oleh guru.

Hal ini sejalan dengan penelitian yang dilakukan oleh Darma (2014), hasil penelitian adalah sebagai berikut. (1) Terdapat perbedaan pemahaman konsep dan kreativitas antara siswa yang diberikan model pembelajaran Inkuiri bebas, model pembelajaran generatif dan model pembelajaran langsung $(\mathrm{F}=26,245$; $\mathrm{p}<0,05)$. (2) Terdapat perbedaan pemahaman konsep antara siswa yang dibelajarkan dengan model pembelajaran inkuiri bebas, model pembelajaran generatif, dan model pembelajran langsung $(F=37,769 ; p<0,05)$. (3) Terdapat perbedaan kreativitas siswa yang diberikan model pembelajaran inkuiri bebas, model pembelajaran generatif dan model pembelajaran langsung $(\mathrm{F}=71,605 ; \mathrm{p}<0,05)$.

Pembelajaran sains berkaitan dengan cara mencari tahu tentang alam secara sistematis, sehingga sains bukan hanya penguasaan kumpulan pengetahuan yang berupa fakta-fakta, konsep, atau prinsip-prinsip saja tetapi juga merupakan suatu proses penemuan. Pendidikan sains cenderung diarahkan untuk inkuiri dan berbuat sehingga dapat membantu peserta didik untuk memperoleh pemahaman yang lebih mendalam tentang alam sekitar. Oleh karena itu pembelajaran sains sebaiknya dilaksanakan secara inkuiri untuk menumbuhkan kemampuan berpikir, bekerja dan bersikap ilmiah serta mengkomunikasikannya sebagai aspek penting kecakapan hidup. Salah satu pembelajaran konstruktivis yang memberikan peluang kepada siswa untuk mengkonstruksi pengetahuannya sendiri dan menumbuhkembangkan kemampuan kinerja ilmiah adalah model pembelajaran inkuiri. Inkuiri merupakan suatu rangkaian kegiatan belajar yang melibatkan secara maksimal seluruh kemampuan siswa untuk mencari dan menyelidiki secara sistematis, kritis, logis, analitis, sehingga mereka dapat merumuskan sendiri penemuannya dengan penuh percaya diri. Inkuiri tidak hanya mengembangkan kemampuan intelektual tetapi seluruh potensi yang ada, termasuk pengembangan emosional dan keterampilan inkuiri dimana merupakan suatu proses yang bermula dan merumuskan masalah, merumuskan hipotesis, mengumpulkan data, menganalisis data, dan membuat kesimpulan. Model pembelajaran inkuri bebas menempatkan siswa seolah-olah bekerja seperti ilmuwan. Siswa diberikan kebebasan untuk menentukan permasalahan untuk penyelidikan, menemukan dan menyelesaikan masalah secara mandiri. Selama proses ini, bimbingan dari guru sangat sedikit diberikan atau bahkan tidak diberikan sama sekali, sehingga memungkinkan siswa untuk memecahkan masalah open ended. Pembelajaran dengan model inkuiri bebas mencakup proses 
mengajukan permasalahan, memperoleh informasi, berpikir kreatif tentang kemungkinan penyelesaian masalah, membuat keputusan, dan membuat kesimpulan.

Pembelajaran inkuri bebas merupakan model pembelajaran yang berupaya menanamkan dasar-dasar berpikir ilmiah pada diri siswa, sehingga dalam proses pembelajaran siswa lebih banyak belajar sendiri dan mengembangkan kreativitasnya dalam memecahkan masalah, sehingga siswa benar-benar ditempatkan sebagai subjek pebelajar. Berdasarkan tahapan-tahapan pembelajaran inkuiri diharapkan terjadi proses pembelajaran yang menyenangkan sehingga bermuara pada pencapaian pemahaman konsep yang baik. Karakteristik kegiatan inkuiri bebas yaitu, (1) Siswa mengembangkan kemampuannya untuk melakukan observasi khusus untuk membuat inferensi; (2) Sasaran belajar adalah proses pengamatan kejadian, objek dan data yang kemudian mengarahkan pada perangkan generalisasi yang sesuai; (3) Guru hanya mengotrol ketersediaan materi dan menyarankan materi inisiasi; (4) Dari materi yang tersedia siswa mengajukan pertanyaan-pertanyaan tanpa bimbingan guru (Dasna dkk.,2015).

\section{Simpulan}

Berdasarkan hasil pengujian hipotesis dan pembahasan tersebut dapat disimpulkan, sebagai berikut. (1) Terdapat perbedaan pemahaman konsep siswa dan berpikir kreatif antara kelompok siswa yang belajar dengan pembelajaran inkuiri bebas dan kelompok siswa yang belajar dengan pembelajaran inkuiri terbimbing. (2) Terdapat perbedaan kemampuan berpikir kreatif siswa antara kelompok siswa yang belajar dengan pembelajaran inkuiri bebas dan kelompok siswa yang belajar dengan pembelajaran inkuiri terbimbing. (3) Terdapat perbedaan pemahaman konsep siswa antara kelompok siswa yang belajar dengan pembelajaran inkuiri bebas dan kelompok siswa yang belajar dengan pembelajaran inkuiri terbimbing.

\section{Daftar Pustaka}

Amalia, P. W., Budi, P. A. P., \& Supriyanto. (2012). Pengaruh penerapan strategi metakognitif dalam metode inkuiri terhadap pemahaman konsep. Unnes Journal of Biology Education. 1(3), 266-271.

Dahar, R.W. (1989). Teori-teori belajar. Jakarta: Erlangga.

Darma, W. Sadia, I. W. Suma, K. (2014). Studi komparatif model pembelajaran inkuiri bebas dan generatif terhadap pemahaman konsep dan kreativitas siswa. e-Journal Program Pascasarjana Universitas Pendidikan Ganesha, 1(4), 1-12.

Dasna, I.W., Laksana, D.N.L. dan Sudatha I.G.W. (2015). Desain dan Model Pembelajaran Inovatif dan Interaktif. Tangerang Selatan: Universitas Terbuka

Provasnik, S. (2012). Highlights From TIMSS 2011 Mathematics and Science Achievement of U.S. Fourth-and Eighth-Grade Students in an International Context. Diterima melalui www.nces.ed.gov/pubs2013/2013009 1.pdf.

Sadia, I. W. (2014). Model-model pembelajaran sains konstruktivistik. Yogyakarta: Graha Ilmu.

Soyomukti, N. (2008). Pendidikan berspektif globalisasi. Jogjakarta: AR-Ruzz Media.

Suma, K. (2009). Pendidikan guru abad ke-21. Orasi Ilmiah. Disampaikan pada Sidang Terbuka Senat Universitas Pendidikan Ganesha, Singaraja, 31 Oktober 2009.

Suma, K. (2015). Fisika konseptual (suplemen bahan ajar berbasis teks sangkalan). Singaraja:Universitas Pendidikan Ganesha.

Sund, R. B. \& Trowbridge, L. W. (1973). Teaching Science by Inquiry in the Secondary School. USA: Bell \& Howell Company.

Yustini, P. E. (2015). Analisis komparasi penggunaan model pembelajaran inkuiri bebas dan inkuiri terbimbing terhadap pemahaman konsep biologi ditinjau dari gaya kognitif siswa SMA. e-Journal Program Pascasarjana Universitas Pendidikan Ganesha Program Studi Pendidikan IPA. 5(1), 1-12. 